\title{
Kadın, Erkek, Ya Da? Hediye Satın Alma Davranışında Cinsiyet Kimliği Rolünün Etkisi
}

\author{
Woman, Man, Or? Gender Role Identity's Effect On Gift Purchasing Behavior
}

Tuğba KILIÇER', Elif BOYRAZ², Adem TÜZEMEN

\begin{abstract}
ÖZET
Bu çalışmanın amacı tüketicilerin hediye satın alma davranışlarında cinsiyetlerinin ve cinsiyet kimliği rollerinin etkisini ortaya koymaktır. Bu bağlamda bir devlet üniversitesinin akademik ve idari personeli anakütle olarak belirlenmiş ve kolayda örnekleme yöntemiyle belirlenen 320 personele yüzyüze anket uygulanmıştır. Elde edilen veriler SPSS paket programı yardımıyla frekans, bağımsız iki örneklem t-testi, faktör analizi, tek yönlü varyans analizi ve kümeleme analizine tabi tutulmuştur. Sonuçlar kadınlarla erkeklerin hediye satın alma davranışlarının farklılaştığını, kadınların hediyeye daha çok önem atfettiklerini ve erkeklerden daha çok hediye satın aldıklarını göstermektedir. Katılımcılar cinsiyet kimliği rollerine göre kümelere ayrılmış ve androjenler, belirsizler ve feminenler olmak üzere üç küme elde edilmiştir. En az hediye satın alan küme belirsizler kümesi iken, en çok hediye satın alan küme androjenler kümesidir. Bu bulgular ışığında uygulayıcılara ve araştırmacılara öneriler geliştirilmiştir.
\end{abstract}

Anahtar Kelimeler: Hediye satın alma ve verme, Cinsiyet Kimliği, Feminen, Maskulen

\section{GiRiş}

Günümüz pazarlama dünyasında tüketiciler herhangi bir mal ya da hizmetin satın alma kararını verirken yalnızca o ürünün faydası üzerine düşünmemekte, aynı zamanda sembolik anlamlarını da tüketme kararı vermektedir. Ürünlerin satın alma motivasyonlarında yaşanan bu değişim tüketicilerin tüketime bakışını ve tüketim tanımlamalarını da değiştirmektedir. Tüketici, tüketimi sosyalleşmenin bir yolu olarak görmekte ve satın alınan ürünleri de sosyalleşmenin aracı haline getirmektedir. Bu

\section{ABSTRACT}

The purpose of the study is to determine the effect of gender and gender role identity on the consumers' gift purchasing behavior. In this context academic and administrative employees of a state university were identified as population of the study and a questionnaire was applied to 320 employees that were selected by conveniency sampling. Frequency, independent samples t-test, factor, One Way ANOVA and cluster analysis were applied to data by SPSS pocket program. The results shows that consumers' gift purchasing behavior of women and men are statistically different. Women give more importance than men to gifting and purchase gifts more than men. Respondents were clustered by gender role identity and three clusters were achieved that were named as androgynous, unidentified and feminines. Unidentified respondents purchase less, on the other hand androgynous respondents purchase more. In light of these results some suggestions were developed for practitioners and researchers.

Key Words: Gift purchasing and gift-giving, Gender Role Identity, Feminine, Masculine

bağlamda sosyal bağları kuvvetlendirmenin bir başka yolu olan hediyeleşmenin satın alma kararları ve satın alma motivasyonları düzleminde incelenmesi önemlidir.

Toplumsal dayanışmanın kaynağının hediyeleşme ilişkisi olduğunu savunan düşünceye göre, toplumsal ilişkilerin devamlılığ hediyenin karşılıklılık ilkesi ile sağlanmaktadır. Bir başkasından hediye alma durumunda karşıığını verme zorunluluğu insanlar arasındaki etkileşimin sürekliliğini sağlamakta, aralarındaki bağı güçlendirmektedir. Bu ilişki ağıyla, 
nesnelerin aktarımıyla birlikte duyguların ve kültürün aktarımı da gerçekleşmektedir (Demez, 2011). $\mathrm{Bu}$ nedenle hediye alma ve verme davranışının pazarlama bağlamında incelenmesi yalnızca bireysel satın almaların anlaşımasına değil, toplumun tüketim tutum ve davranışlarının anlaşılmasına da katkı sağlayacaktır.

Belk ve Coon (1993, akt. Larsen ve Watson, 2001) hediyeyi bir kişiye veya gruba gönüllü olarak sunulan bir mal ya da hizmet olarak tanımlamaktadır. Başka bir deyişle hediye, biri tarafından alıcıya sunulan faydadır. Hediyeyi yalın bir şekilde bir nesne olarak ifade etmek yaygın bir yaklaşım olmakla birlikte, hediyenin anlamını ifade etmekten uzaktır. Bir hediyenin bir nesne olmaktan öte özellikleri vardır ki bu özellikler hediyeyi satın alana, hediyeyi verdiği kişiye, aralarındaki ilişkiye ve hediyenin sunuluş şekline bağlıdır. Bu nedenle hediyeden ziyade hediye verme deneyimi üzerine konuşmak daha doğru bir yaklaşımdır (Larsen ve Watson, 2001). Hediyenin tüketici davranışları açısından incelenmesi gereken pek çok boyutu vardır. Hediye ekonomik bir anlam ifade etmenin yanı sıra aynı zamanda sosyal ve fonksiyonel bir anlam da ifade etmektedir (Larsen ve Watson, 2001; Sherry, 1983). Hediyenin ekonomik boyutu bireyler arasındaki bir mübadele aracı olmasıyla ilgiliyken, sosyal boyutu toplumsal birlikteliği devam ettirmenin bir yolu olmasıly ilgilidir. Hediyenin fonksiyonel anlamı ise hediye satın alan tarafından sevdiği, değer verdiği bir kişiye sunduğu bir faydayı ifade etmektedir.

Tüketici davranışlarını etkileyen çok sayıda kültürel, sosyal, kişisel ve psikolojik faktörler olmakla birlikte tüketici davranışı araştırmalarında en çok üstünde durulan faktörlerden biri cinsiyettir. Cinsiyet tüketici davranışlarını açıklamada önemli bir pazar bölümlendirme değişkenidir ve pazarlama yazınında tüketici tutum ve davranışlarında cinsiyet temelli farklılaşmaları konu edinen çok sayıda çalışma mevcuttur. Tüketim araştırmalarında demografik bir faktör olarak incelenen cinsiyet biyolojik cinsiyeti yani yabancı yazındaki "sex" kelimesini ifade etmektedir. 1930 'lardan itibaren psikoloji yazınına giren, 1960'lardan itibaren ise tüketim araştırmalarında incelenen "cinsiyet kimliği" ise psikolojik cinsiyeti ifade etmektedir (Çabuk, 2013) ve maskulen ve feminen kelimeleri bireylerin cinsiyet kimliklerini tanımlamak için kullanılmaktadır.

Maskulenlik etkili bir yönelim olarak birbirini etkileme sürecinde hedeflere ulaşmadaki başarıyla ilgilidir. Nesneleri, çevreyi ve insanları manipüle ederek işlerin üstesinden gelmeyi ifade etmektedir. Maskulen yönelim formal otoriteyi ve teknik kontrolü kullanmakta, amaca odaklanmakta ve onay, saygınlık ve önem gibi kişisel olmayan tutumlarla desteklenmektedir. Feminen yönelim ise anlamlı bir yönelimdirve bizzat etkileşim sürecini kolaylaştırmaya öncelik vermektedir. Feminen yönelim kendisinin ve diğerlerinin duygularını anlamak ve bu duygularla ilgilenmek üzerine kuruludur. Bununla birlikte duygusal olmayı değil, karşılıkı bağımlı ve ilişkili olmayı temsil etmektedir. Etkili bir yönelim olmak yerine anlamlı bir yönelim olmak, genellikle aşk ve arkadaşlık gibi kişisel tutumlarla ödüllendirilmektedir (Palan vd., 2001). Her ne kadar maskulen kişilikyapısına atfedilen sıfatlar erkeklerle, feminen kişilik yapısına atfedilen sıfatlar kadınlarla ilişkilendirilse de cinsiyet kimliği cinsiyetten farklı bir özelliği ifade etmektedir. $\mathrm{Bu}$ sebeple maskulen kadınlar var olduğu gibi feminen erkekler de mevcuttur. Cinsiyet ve cinsiyet kimliği arasındaki bu farklılık tüketim araştırmalarında her iki değişkenin de kullanılması gerektiğini ortaya koymaktadır. Maskulen kadının tüketim kararları erkeklerle benzerlik gösterebilecekken, feminen erkeğin tüketim kararları da kadınınkine benzerlik gösterebilecektir.

Hediyenin bireyler arasındaki bağları kuvvetlendirme ve etkileşimin devamlılığını sağlama fonksiyonları dikkate alındığında hediye satın alma kararlarında cinsiyetten ziyade cinsiyet kimliği rolünün etkisinin incelenmeye değer olduğu görülmektedir. Hediye dostluğun, bağlılı̆ın, aşkın vb. bir ifadesi olduğu için bireylerin cinsiyetleri temelinde satın alma kararları vereceği varsayımı hediye alışverişlerinde geçerli olmayabilir.

$\mathrm{Bu}$ bağlamda araştırmanın amacı tüketicilerin hediye satın alma davranışlarında cinsiyetlerinin ve cinsiyet kimliği rollerinin etkisini belirlemek ve karşılaşılabilecek muhtemel farklııklar ışığında uygulayıcılara pazar bölümlendirme ve hedef pazar seçimi stratejileri önermektir.

\section{LITERATÜR ÖZETI}

Yapılan literatür taraması neticesinde yerli yazında tüketicilerin hediye satın alma davranışlarına pazarlama perspektifinden yaklaşan araştırmaya rastlanmamıştır. Yabancı yazında ise hediye satın alma davranışının yanı sıra hediye verme davranışını da konu edinen çok sayıda çalışma yer almaktadır. 
Yabancı yazında yapılan incelemeler hediye alma ve verme davranışında kültürel farklılıkların var olduğu izlenimini yaratmaktadır. Söz konusu davranışı tanımlarken kullanılan filler dahi (hediye alma/ verme) kültürel olarak farklılaşmaktadır. Bu sebeple yerli yazında da hediye satın alma davranışının incelenmeye değer bir konu olduğu düşünülmektedir. Yabancı yazında hediye satın alma ve verme davranışının cinsiyete göre farklılaşmasını konu edinen çok sayıda çalışma mevcuttur. Bu çalışmaların bulguları, kadınların kendilerine ve başkalarına hediye vermeye erkeklerden daha meyilli olduklarını (Ward ve Tran, 2007; Minowa vd., 2011; Areni vd., 1997; Shanka ve Handley, 2011; Areni vd., 1998), hediye seçiminde daha başarılı olduklarını (Huang ve Yu, 2000; Wolfinbarger ve Gilly, 1996; Pollmann ve Beest, 2013) buna karşılık hediye verme anılarından ziyade hediye alma anılarını hatırladıklarını (Areni vd., 1997; McGrath, 1995; Areni vd., 1998), romantik ilişkilerinde hediyenin sembolik anlamına önem verip, sunmayı bir seremoniye dönüştürdüklerini (Schiffman ve Kohn, 2009; McGrath, 1995), diğer hediyeleşmelerinde ise ekonomik davrandıklarını (Minami, 1994) ortaya koymaktadır. Otnes vd. (1994) ise çalışmalarında sanılanın aksine erkeklerin özel günlerde hediye veren taraf değil alan taraf olmak istediklerini, şaşırtılmaktan hoşlandıklarını, özel günlerde yalnız kaldıklarında kendine hediye verme davranışı sergilediklerini vurgulamaktadır.

Yabancı yazında cinsiyetin yanı sıra cinsiyet kimliği rolü açısından hediye alma ve verme davranışının nasıl farkılış̧ığını konu edinen çalışmalar da mevcuttur. Aşağıda bu çalışmaların bulgularına yer verilecektir.

Fischer ve Arnold (1990) çalışmalarında "Christmas" alışverişlerinde cinsiyet rolünün etkisi üzerinde durmuşlardır. Araştırma bulguları kadınların yılbaşı alışverişine erkeklerden daha istekli olduklarını göstermektedir. Bununla birlikte eşitlikçi olduklarını ifade eden erkeklerin de yılbaşı hediyeleşmelerine ilgilenimlerinin daha yüksek olduğunu ortaya koymaktadır. Araştırma sonuçları, yılbaşı hediyeleşmesinin bir "aşk işçiliği" olarak görülmesine rağmen bir kadın işi olarak yorumlandığını göstermektedir. Kadınlar erkeklerden daha çok sayıda hediye almakta, daha erken hediye almaya başlamakta, hediye başına daha çok zaman, daha az para harcamakta ve hediye seçiminde daha başarılı olmaktadır. Eşitlikçi erkekler geleneksel erkeklerden ve aynı düzeyde eşitlikçi kadınlardan daha çok hediye almakta, daha çok zaman harcamaktadır. Eşitlikçi kadınlar ise geleneksel kadınlardan ve aynı düzeyde eşitlikçi erkeklerden daha az vakit harcamakta ve hediye başına daha çok para harcamaktadır. Bunun yanı sıra feminen kişilikler daha çok hediye alışverişi yapmaktadır.

Webster ve Nottingham (2000) hediye satın alma motivasyonunda cinsiyetin ve cinsiyet kimliğinin rolü üzerinde durmuşlardır. Araştırma bulguları kadınların, feminenlerin ve tanımlanamayan cinsiyet kimliğine sahip tüketicilerin maskulen ve androjen bireylerden daha çok hediye satın almaya meyilli olduklarını ortaya koymaktadır. Kadınlar hediye satın almada daha çok deneyimsel ve pozitif motivasyonlara sahipken erkekler pratik motivasyonlara sahiptir. Bunun yanı sıra feminenler pozitif motivasyonlarla, maskulenler pratik motivasyonlarla, hem feminen hem maskulenler zorlayıcı motivasyonlarla hediye satın almaktadır.

Palan vd. (2001) hediye alışverişlerinde cinsiyet kimliğinin rolünü belirlemeye çalıştıkları araştırmalarında kadın/erkek ve feminen/maskulen kimlik karşılaştırmalarına yer vermişlerdir. Araştırma bulgularına göre erkekler kadınlardan daha çok hediye verme anılarını hatırlamaktadır. Benzer şekilde maskulen bireyler de hediye verme anılarını feminenlerden daha çok hatırlamaktadır. Kadınlar hediye alışverişlerinde birey odaklı hareket ederken, erkekler amaç odaklı hareket etmektedir. Feminen kadınlar maskulen kadınlardan daha çok insan odaklı iken, maskulen erkekler feminen erkeklerden daha çok amaç odaklıdır.

Dalakas ve Shoham (2010) İsrail'deki tüketicilerin hediye satın alma kararlarında cinsiyet kimliği rollerinin etkisini konu edinmiş ve araştırma hipotezlerini özellikle bireylerin eşitlikçi tutumlarının satın almaları üzerindeki etkisine odaklamışlardır. Araştırma bulguları eşitlikçiliğin yalnızca kadınların satın alma kararlarında ve yıldönümü hediyelerinde etkili olduğunu göstermektedir.

Klein vd. (2015) Nazi kamplarından Yahudi soykırımı sonrası kurtulanların hatıratlarından yola çıkarak hediye verme davranışının kimlik temelli motivasyonlarını incelemişlerdir. Araştırma bulguları toplama kamplarının cinsiyet kimliğini ortadan kaldıran katı kurallarıyla baş etmede hediyeleşmenin bir yol olduğunu ortaya koymaktadır. Feminen yanları üniformalar, saç tıraşları ve kurallarla törpülenen kadınlar feminen kimliklerini ifade etmek için hediye verme davranışını bir kurtarıcı olarak görmektedirler. 


\section{ARAŞTIRMANIN YÖNTEMI}

$\mathrm{Bu}$ araştırmada; tüketicilerin cinsiyet, cinsiyet kimliği rolleri ve hediye satın alma davranışı açısından profilleri ile genel olarak hediye satın alma davranışlarını ortaya çıkarmak için betimsel araştırma modelinden faydalanılmıştır.

Araştırmanın genel amacı doğrultusunda şu sorulara cevap aranmıştır:

1. Tüketicilerin hediye satın alma davranışları cinsiyet ve cinsiyet kimliği rolleri açısından farklılaşmakta midır?

2. Tüketiciler hafızalarındaki hediye alma ve verme hatıraları açısından nasıl bir görünüm sergiliyorlar?

3. Tüketiciler genel olarak hediye satın alma davranışı açısından nasıl bir görünüm sergiliyorlar?

4. Hediye satın alma davranışı cinsiyete göre farklılık gösteriyor mu?

5. Tüketiciler son altı aylık dönemde yaşadıkları hediye satın alma deneyimleri açısından nasıl bir görünüm sergiliyorlar?

Araştırmanın anakütlesi bir devlet üniversitesinin merkez kampüsünün akademik ve idari birimlerinde çalışan toplam 1547 (933 akademik, 614 idari) personelden oluşmaktadır. Zaman ve ulaşılabilirlik kısıtları göz önünde bulundurularak kolayda örnekleme yöntemiyle örneklem seçme yoluna gidilmiştir. Bu doğrultuda daha dengeli bir dağılım elde etmek amacıyla üniversitenin enstitüleri, fakülteleri, meslek yüksekokulu ve yüksekokulları ile rektörlüğe bağlı birimlerin büyük bir bölümüne ulaşılmaya çalışılmıştır. Saha çalışması sonucunda toplam 324 kişiye ulaşılmıştır. Yapılan incelemeler sonucunda 4 anketin eksik ve hatalı doldurulduğu belirlenmiş ve kullanılabilir olan 320 adet form üzerinden analizler gerçekleştirilmiştir.

Verilerin toplanmasında yüzyüze anket tekniğinden faydalanılmıştır. Veriler 10 Şubat 2015 ile 17 Şubat 2015 tarihleri arasında yürütülen yedi günlük saha çalışmasıyla ardından toplanmıştır. Beş bölümden oluşan veri toplama aracı toplam 51 soru ve ifadeden oluşmaktadır. Birinci bölümde katılımcılara genel olarak hediye satın alma davranışları ile ilgili 6 açık uçlu soru sorulmuştur. Bu bölümde katılımcılardan ayrıca hediye satın alma davranışıyla ilgili 4 ifadeye ne düzeyde katıldıklarını cevaplandırmaları istenmiştir. Veri toplama aracının ikinci bölümünde katılımcıların hediye satın alma davranışlarını belirlemeye yönelik 7 ifade, üçüncü bölümünde ise cinsiyet kimliklerini belirlemeye yönelik 20 ifade yer almaktadır. Hediye satın alma davranışını ölçmek için Beatty vd.'nin (1991) geliştirdiği ölçek, cinsiyet kimliği rolünü ölçmek için ise Schertzer vd.'nin (2008) uyarladığı ölçek kullanılmıştır. Schertzer vd. (2008) Bem tarafından geliştirilen Cinsiyet Rolü Envanteri'ni (Gender Role Inventory) geçerlilik testi yaparak, özellikle pazarlama araştırmalarında kullanılmak üzere yeniden uyarlamışlardır. Cinsiyet kimliğini belirlemek amacıyla bu ölçek kullanılmıştır. Katılımcılarikinciveüçüncü bölümdeyeralan ifadelere ne düzeyde katılıp katılmadıklarını 5'li Likert ölçeğine göre cevaplandırmışlardır (1:Kesinlikle Katılmıyorum; 2:Katılmıyorum; 3:Ne Katılıyorum Ne Katılmıyorum; 4:Katılıyorum; 5:Kesinlikle Katılıyorum). Veri toplama aracının dördüncü bölümünde katılımcıların demografik özelliklerini belirlemeye yönelik 6 kapalı uçlu soruya yer verilmiştir. Beşinci ve son bölümde ise katılımcıların son 6 ayda yaşadığı hediye satın alma deneyimlerini ortaya çıkarmak amacıyla 4 adet kapalı uçlu ve 2 adet açık uçlu soru sorulmuştur.

Veri toplama aracına son şekli verilmeden önce kapsam ve görünüş geçerliğinin sağlanması adına 3 alan uzmanından oluşan bir uzman paneli yapılmıştır. Uzmanların, ifadelerin ölçülmek istenen değişkenleri kapsayıp kapsamadığı ve biçimsel açıdan uygunluğu konusunda yaptıkları değerlendirmeler sonucunda gerekli düzeltmeler yapılmıştır. Görünüş geçerliğinin sağlanması için, veri toplama aracı bir Türkçe dil uzmanı tarafından da değerlendirilmiştir.

Veri toplama aracında cinsiyet kimliğiyle ilgili ifadelerin yapı geçerliğini test etmek için açıklayıcı faktör analizi kullanılmıştır. Faktör modelinin doğruluğunu test etmek için yapılan incelemede KMO değerinin 0,865 olarak hesaplandığı, Bartlett küresellik testinin ve Ki-Kare değerinin anlamlı çıktığı ( $p$ <.05) görülmüştür. Ölçekteki 5. faktörü oluşturan iki ifade (agresif, baskın) güvenilirlik düzeyi düşük olduğu için ölçekten çıkarılmıştır. Tablo 1'de görüldüğü üzere cinsiyet kimliğini belirlemeye yönelik 18 ifade, özdeğeri 1'in üzerinde 4 faktör altında toplanmıştır. Bu faktörleri açıklayan toplam varyans büyüklüğü ise \% 66.38'dir. Analize sokulan 18 ifadeden maskulen ve feminen kimlikle ilişkili birer ifadenin faktör yük değerleri arasındaki fark 0,10'dan küçüktür. Bu ifadeler kararsız maddeler olması nedeniyle atılmıştır. Kalan 16 ifadeye ilişkin faktör yük değerlerinin sınır değerin üzerinde olduğu görülmektedir. 
Tablo 1: Cinsiyet Kimliğine İlişkin Faktör Analizi Sonuçları

\begin{tabular}{lccc}
\hline & Faktörler & & \\
\hline Maddeler & $\mathbf{1}$ & $\mathbf{2}$ & $\mathbf{3}$ \\
\hline 1. Faktör: Sevecenlik & & $\mathbf{4}$ \\
Sevimli & 0,805 & \\
Sempatik & 0,799 & \\
Sıcak & 0,771 & \\
Sicakkanlı & 0,759 & \\
\hline
\end{tabular}

\section{Faktör: Nezaket}

Başkalarının ihtiyaçlarına karşı duyarlı $\quad 0,797$

$\begin{array}{ll}\text { Şefkatli } & 0,689\end{array}$

$\begin{array}{lr}\text { Nazik } & 0,672\end{array}$

İradeli $\quad 0,658$

$\begin{array}{lr}\text { Sadık } & 0,625\end{array}$

\section{Faktör: Güçlülük}

$\begin{array}{ll}\text { Lider ruhlu } & 0,781\end{array}$

$\begin{array}{ll}\text { Liderlik yeteneğine sahip } & 0,780\end{array}$

$\begin{array}{ll}\text { Güçlü kişiliğe sahip } & 0,625\end{array}$

Depresif duyguların üstünden gelmede başarılı $\quad 0,587$

$\begin{array}{ll}\text { Fikrini rahatlıkla açıklayabilen } & 0,580\end{array}$

\section{Faktör: Rekabet}

Hırslı

Rekabetçi

Özdeğer

6,24

Açıklanan Varyans (\%)

39,00

1,93

1,83

Cronbach a

0,862

12,06

1,26

7,39

KMO Testi: 0,865 Bartlett küresellik testi

$X^{2}: 2302,369$ df: 120 p: 0,00

Analiz sonucu ortaya çıkan ilk iki faktör genel olarak feminen kimlik özelliklerini, 3 ve 4. faktör ise genel olarak maskulen kimlik özelliklerini ifade etmektedir. Yalnızca ikinci faktördeki iradeli ifadesi ile üçüncü faktördeki depresif duyguların üstesinden gelmede başarılı ifadeleri orijinal ölçekteki yapıdan farklı faktörlerde yer almaktadır. Faktör yapıları incelenerek 1. faktör sevecenlik, 2. faktör nezaket, 3. faktör güçlülük, 4. faktör rekabet olarak adlandırılmıştır.

Veri toplama aracında yer alan yapıların iç tutarlılık anlamında güvenirliğini belirlemek için Cronbach'ın a korelasyon katsayısı hesaplanmıştır. Cinsiyet kimliğiyle ilişkili faktörler (Tablo 1) ile hediye satın alma davranışına $(a=0,782)$ ilişkin katsayıların Malhotra'nın (2007) önerdiği 0,60 sınırının üstünde yer aldığı görülmüştür.

Araştırmada betimsel verilerin analizinde aritmetik ortalama, standart sapma ve yüzde hesaplamalarından faydalanılmıştır. Katılımcıların cinsiyet, cinsiyet kimliği rolleri ve hediye satın alma davranışları açısından profilleri kümeleme analizi ve tek yönlü varyans analizi kullanılarak belirlenmiştir. Hediye satın alma davranışının cinsiyet açısından farklılaşıp farklılaşmadığı $t$ testi kullanılarak test edilmiştir.Verilerin analizinde SPSS paket programının 20. sürümünden faydalanılmıştır. 


\section{BULGULAR ve TARTIŞMA}

Cevaplayıcıların demografik özellikleri aşağıdaki tabloda sunulmaktadır.

Tablo 2: Katılımcıların Demografik Özellikleri

\begin{tabular}{|c|c|c|c|c|c|c|c|}
\hline $\begin{array}{c}\text { Demografik } \\
\text { Özellik }\end{array}$ & & $\mathbf{n}$ & $\%$ & $\begin{array}{c}\text { Demografik } \\
\text { Özellik }\end{array}$ & & $\mathbf{n}$ & $\%$ \\
\hline \multirow{4}{*}{ Cinsiyet } & Kadın & 107 & 33,4 & \multirow{4}{*}{ Kadro } & Akademik & 212 & 66,3 \\
\hline & Erkek & 212 & 66,3 & & İdari & 99 & 30,9 \\
\hline & Cevapsız & 1 & 0,3 & & Cevapsız & 9 & 2,8 \\
\hline & Toplam & 320 & 100 & & Toplam & 320 & 100 \\
\hline \multirow{9}{*}{ Gelir } & 1000 TL'den az & 10 & 3,1 & \multirow{9}{*}{ Medeni Hal } & Evli & 216 & 67,5 \\
\hline & $1001-2000 \mathrm{TL}$ & 25 & 7,8 & & Dul & 3 & 0,9 \\
\hline & 2001-3000 TL & 62 & 19,4 & & Boşanmış & 7 & 2,2 \\
\hline & $3001-4000 \mathrm{TL}$ & 131 & 40,9 & & Sözlü & 7 & 2,2 \\
\hline & 4001-5000 TL & 52 & 16,3 & & Nişanlı & 2 & 0,6 \\
\hline & $5001-6000 \mathrm{TL}$ & 19 & 5,9 & & Bekarım, ilişkim var & 16 & 5 \\
\hline & 6001 TL ve üstü & 19 & 5,9 & & Bekarım ilişkim yok & 65 & 20,3 \\
\hline & Cevapsız & 2 & 0,6 & & Cevapsız & 4 & 1,3 \\
\hline & Toplam & 320 & 100 & & Toplam & 320 & 100 \\
\hline \multirow{7}{*}{ Yaş } & $18-25$ & 20 & 6,3 & \multirow{7}{*}{ Eğitim } & Lise & 22 & 6,9 \\
\hline & $26-35$ & 137 & 42,8 & & Önlisans & 20 & 6,3 \\
\hline & $36-45$ & 95 & 29,7 & & Lisans & 62 & 19,4 \\
\hline & $46-55$ & 47 & 14,7 & & Yüksek lisans & 76 & 23,8 \\
\hline & $56-65$ & 8 & 2,5 & & Doktora & 136 & 42,5 \\
\hline & Cevapsız & 13 & 4,1 & & Cevapsız & 4 & 1,3 \\
\hline & Toplam & 320 & 100 & & Toplam & 320 & 100 \\
\hline
\end{tabular}

Katılımcıların demografik özellikleri incelendiğinde cinsiyet açısından erkeklerin, yaş açısından 26-35 yaş grubunun, medeni durum açısından evlilerin, eğitim açısından doktora mezunlarının, gelir açısından 3001-4000 TL gelir grubunun, kadro açısından akademik personelin ağırlıkta olduğu görülmektedir.

\subsection{Katılımcıların Hediye Satın Alma}

Davranışlarına İlişkin Değerlendirmeler

Anketin açık uçlu sorulardan oluşan kısmında katılımcılardan hafızalarında yer eden bir hediye verme ya da alma hatıralarını detaylı bir şekilde (yer, zaman, hediye verilen/alınan kişi, hediye verme/alma nedeni vb.) anlatmaları istenmiştir. Bu açık uçlu soruya verilen cevaplar araştırmacılar tarafından ayrı ayrı incelenmiş, uyuşmazlıkların çözümü için sonradan birlikte değerlendirilmiştir. Verilen cevaplar hediye alma hatırası mı, hediye verme hatırası mı oldukları yönünde ve ilgili anıda hediye verenin odağı (kişi odaklı/amaç odaklı) bağlamında değerlendirilmiştir. Değerlendirme sonuçları aşağıdaki tabloda görülmektedir. 
Tablo 3: Katılımcıların Hediye Alma/Verme Hatıralarına İlişkin Değerlendirmeler

\begin{tabular}{llcc}
\hline & & $\mathbf{n}$ & $\%$ \\
\hline \multirow{3}{*}{ Hatıranın Türü } & Hediye Alma & 70 & 21,9 \\
& Hediye Verme & 147 & 45,9 \\
& Cevapsız & 103 & 32,2 \\
& Toplam & 320 & 100 \\
\hline & Birey Odaklı Kadın & 17 & 5,3 \\
Birey Odaklı Erkek & 42 & 13,1 \\
Hediye Verenin & Amaç Odaklı Kadın & 37 & 11,6 \\
& Amaç Odaklı Erkek & 79 & 24,7 \\
& Birey Odaklı Cinsiyet Belirsiz & 13 & 4,1 \\
& Amaç Odaklı Cinsiyet Belirsiz & 20 & 6,3 \\
& Odağı Belirsiz Kadın & 1 & 0,3 \\
& Odağı Belirsiz Erkek & 7 & 2,2 \\
& Cevapsız & 104 & 32,5 \\
& Toplam & 320 & 100 \\
\hline
\end{tabular}

Tabloda sunulan bulgulara göre cevaplayıcılar hediye alma anılarından çok hediye verme anılarını hatırlamaktadır. Hatırlanan anıda hediye veren kişinin seçtiği hediye, sunum şekli, sunum zamanlaması vb. dikkate alınarak bireye odaklı mı yoksa amaca odaklı (özel gün kutlaması, ihtiyacı giderme çabası vb.) mı olduğu belirlenmeye çalışılmıştır. Cevaplayıcıların hikaye ettikleri hatıralarında hediye veren taraf ağılıklı olarak amaç odaklı hareket etmektedir. Literatürdeki çalışmalar hediyeleşmede odağın hediye verenin cinsiyetine göre farklılaştığını ortaya koymakta ve kadınların daha çok birey odaklı hediye seçtiklerini vurgulamaktadır. Ancak araştırma bulguları cevaplayıcıların hatıralarındaki hediye verme anılarının cinsiyete bağlı olmaksızın ağırlıklı olarak amaç odaklı olduğunu göstermektedir. Bu farklılığın kültürel kabullerden kaynaklandığı düşünülmektedir. Toplumumuzda hediyenin aynı zamanda bir yardımlaşma aracı olarak görülmesi ve bu sebeple intiyaç gidermesi gerektiği düşüncesi bu dağıımın en önemli sebebi olarak görülmektedir.

Anketin açık uçlu sorularının bulunduğu ilk kısımda katılımcılara hediye alışverişlerine yıllık ortalama ne kadar harcama yaptıkları, alışveriş için ne kadar vakit ayırdıkları, yılda ortalama kaç adet ve kaç farklı kişiye hediye aldıkları ve hediye seçiminde başarılı olup olmadıklarına ilişkin öz değerlendirmeleri sorulmuştur. Katılımcılar hediye alışverişlerine yıllık ortalama 895,33 TL para ve yaklaşık 3 gün $(2,89)$ vakit harcamaktadır. Yılda ortalama 9 adet $(8,76)$ hediye almakta ve ortalama 8 kişiye $(7,41)$ hediye almaktadırlar. Bu bulgular incelendiğinde katılımcıların hediye alışverişine çok da fazla vakit ayırmadıkları ve çok sayıda kişiye hediye almadıkları söylenebilir.

Katılımcılara yakın oldukları kadın ve erkeklere ve yeterince yakın olmadıkları kadın ve erkeklere hediye almanın zorluk derecesi ile ilgili sorular sorulmuş ve beş noktalı ölçek ile (1:çok zor, 2:zor, 3:ne zor ne kolay, 4:kolay, 5:çok kolay) değerlendirmeleri istenmiştir. Yakın bir kadına hediye almayla ilgili ifadenin aritmetik ortalaması 3,20; yeterince yakın olmayan bir kadına hediye almayla ilgili ifadenin aritmetik ortalaması 2,37; yakın bir erkeğe hediye almayla ilgili ifadenin aritmetik ortalaması 3,54; yeterince yakın olmayan bir erkeğe hediye almayla ilgili ifadenin aritmetik ortalaması 2,82'tir. Bu bulgulara göre katılımcılar erkeklere hediye almanın nispeten daha kolay olduğunu, yakın olunan kişilere hediye almanın genel olarak daha kolay olduğunu ifade etmektedirler. Kadınlara hediye almanın zorluğu bulgusu seçilebilecek hediye alternatifinin sayısı düşünüldüğünde dikkat çekicidir. Alternatif çok olmasına karşın, kadınların beklentilerinin yüksek olduğu varsayımının bu sonucu doğurduğu düşünülmektedir.

Katılımcılara son altı ayda hediye alıp almadıkları, aldılar ise bu hediyenin niteliği, hediye alınan kişinin cinsiyeti, kim için satın alındığı, neden satın alındığı ve maliyeti sorulmuştur. Katılımcıların $\% 85$ 'i son altı ay içinde hediye aldıklarını, \%13,4'ü ise almadıklarını ifade etmiştir. Son altı ay içerisindeki hediye satın alma deneyimleri incelendiğinde en çok satın alınan hediyelerin sırasıyla giyim, takı-aksesuar, teknolojik cihazlar, ev eşyası ve mücevher kategorileri olduğu gözlenmektedir. 
En az satın alınan hediyeler ise sırasıyla araba, konut, oyuncak, kitap ve kişisel bakım kategorileridir. Bu hediyelerin \%64,4'ü kadınlar için alınırken, \%19,7'si ise erkekler için alınmıştır. Yine bu hediyelerin \%33,8'i eşler, \%16,6'sı arkadaşlar, \%11,6'sı çocuklar, $\% 7,5^{\prime} \mathrm{i}$ akrabalar, \%5,3'ü anne-babalar, \%5,3'ü ise iş arkadaşları için satın alınmıştır. Satın almaların $\% 27,5$ i doğum günü, $\% 8,8$ 'i Sevgililer Günü, $\% 4,4$ 'ü ise terfi/yükselme/başarı kutlamaları için yapılmıştır. Katılımcıların \%30,6'sı ise herhangi bir sebep olmaksızın sadece içinden geldiği için hediye satın aldığını belirtmiştir. Son altı ay içerisinde satın alınan hediyelerin ortalama maliyeti ise 1736,98 TL'dir. Bu rakamın yıllık ortalama hediye harcaması tutarının çok üstünde olması, örneklemdeki konut ve otomobil hediyelerinin maliyetinden ve verilerin Sevgililer Günü'nün hemen akabinde toplanmış olmasından kaynaklanmaktadır.

Katılımcılara hediyenin ve hediyeleşmenin anlam ve önemine ilişkin önermeler sunulmuş ve ne ölçüde katıldıklarını belirtmeleri istenmiştir. Aşağıdaki tabloda bu ifadelere ilişkin tanımlayıcı istatistiklere yer verilmektedir.

Yukarıdaki tanımlayııı istatistikler incelendiğinde, katılımcıların hediyeleşmeyi dostluğu ve sevgiyi ifade etmenin bir yolu olarak gördükleri, hediye aldıkları kişinin kendisini özel hissetmesini sağlayacak hediyeleri tercih etmeye çalıştıkları ve hediyeleşmek için özel bir gün ya da gerekçeye ihtiyaç duymadıkları görülmektedir. Buna karşın katılımcılar kendilerini başkaları için çok hediye alan biri olarak da tanımlamamaktadır.

Araştırma amacı doğrultusunda öncelikle yukarıdaki ifadelere verilen cevapların cinsiyete göre farklılaşıp farklılaşmadığı incelenmiş ve bağımsız iki örneklem için t-testi kullanılmıştır. Test sonuçları ifade ortalamalarının ( $p=0,000 ; t=4,916)$ yanı sıra üçüncü $(p=0,027 ; t=2,221)$, dördüncü $(p=0,000 ; t=-4,714)$, beşinci $(p=0,000 ; t=3,676)$, altıncı $(p=0,000 ; t=3,883)$ ve yedinci $(p=0,000 ; t=5,485)$ ifadeler açısından da kadınlarla erkeklerin farklılaştıklarını göstermektedir. $\mathrm{Bu}$ sonuçlara göre kadınlar erkeklerden daha çok dostluğu göstermek amacıyla özel hediyeler almakta, çok yakın aile üyelerine satın alacakları hediyelerde erkeklerden daha özenli davranmakta, kişilere özel olduğu mesajını vermeye daha çok odaklanmakta ve hediye seçme ve sunmaya erkeklerden daha çok anlam yüklemektedir. Buna karşılık yalnızca özel gün ve gerekçelerle hediye alma eğilimi erkeklerde kadınlardan daha fazladır.

Tablo 4: Hediye Satın Alma Tutum ve Davranışına Illişkin Önermeler

\begin{tabular}{lcc}
\hline \multicolumn{1}{c}{ Ifadeler } & $\overline{\boldsymbol{X}}$ & $\mathbf{S}$ \\
\hline $\begin{array}{l}\text { 1. Bana göre hediye vermek insanlara sevgini ve dostluğunu göstermenin } \\
\text { önemli bir yoludur. }\end{array}$ & 3,87 & 1,2 \\
\hline $\begin{array}{l}\text { 2. Kendimi başkaları için çok hediye alan biri olarak görüyorum. } \\
\text { 3. Dostluğumu göstermek için insanlara zaman zaman özel hediyeler alııım. }\end{array}$ & 2,76 & 1,10 \\
\hline $\begin{array}{l}\text { 4. Özel bir gün ya da gerekçe olmadıkça başkalarına hemen hemen hiç hediye } \\
\text { almam. }\end{array}$ & 3,22 & 1,16 \\
\hline $\begin{array}{l}\text { 5. Genellikle çok yakın aile üyelerine satın alacağım ya da kendim yapacağım } \\
\text { hediyeler için çok çaba sarf ederim. }\end{array}$ & 3,52 & 1,09 \\
\hline $\begin{array}{l}\text { 6. Genellikle hediye vereceğim kişinin benim için önemli olduğu mesajını verecek } \\
\text { hediyeler seçmeye gayret ederim. }\end{array}$ & 3,69 & 1,13 \\
\hline \begin{tabular}{l} 
7. Özenle hediye seçmek ve vermek benim için önemli bir ritüeldir. \\
\hline
\end{tabular} & 3,44 & 1,20 \\
\hline
\end{tabular}




\subsection{Katılımcıların cinsiyet kimliği rolü, cinsiyet ve hediye satın alma davranışı açısından profilleri}

Katılımcıların cinsiyet kimliği rolü, cinsiyet ve hediye satın alma davranışları açısından profillerini ortaya çıkarmak için kümeleme analizi ve ardından tek yönlü varyans analizi yapılmıştır. Bu doğrultuda öncelikle katılımcıları cinsiyet kimliği rolleri açısından gruplandırmak amacıyla hiyerarşik kümeleme yönteminde en çok tercih edilen tekniklerden biri olan Ward tekniği kullanılmıştır. Bu aşamada faktör analizi sonucunda ortaya çıkan 4 faktör kullanılarak katılımcılar kümelere ayrılmıştır. Hiyerarşik kümelemede uygun küme sayısını belirlemede, yığışım tablosundaki sıçramalar ve dendogram dağılımı incelenmiştir. Bunun yanısıra her bir kümedeki katılımcı sayısının anlamlı olması ile kümelerin özelliklerinin açıklanabilir ve yorumlanabilir olması (Malhotra, 2007; Hair vd., 1998) gibi faktörler göz önünde bulundurularak 3'lü küme seçeneğinin uygun olduğu görüşüne ulaşılmıştır. Üç kümenin her birinde yer alan katılımcı sayısı ve küme ortalamaları Tablo 5'te görülmektedir.

Tablo incelendiğinde 1. kümede yer alan katılımcılar toplam katılımcıların \%63'ünü oluşturmaktadır. Bu kümede yer alan katılımcılar dört faktör açısından ortalamanın üzerinde ve diğer kümelerle karşılaştırıldığında en yüksek ortalamalara sahip kişilerden oluşmaktadır. 1. küme içerisinde yer alan katılımcılar hem feminen hem de maskulen kimlik özelliklerini yüksek düzeyde taşımaktadırlar. Bu nedenle bu küme androjenler olarak adlandırılmıştır.

2. kümede yer alan katılımcılar toplam katılımcıların \%17'sini oluşturmaktadır. 2. küme cinsiyet kimliğini oluşturan dört faktör açısından, ortalamanın altında ortalamalara sahip kişilerden oluşmaktadır. Bir başka ifadeyle bu kümenin katılımcıları feminen ve maskulen kimlik özelliklerini belirgin biçimde taşımamaktadırlar. Bu nedenle ikinci küme belirsizler olarak adlandırılmıştır.

3. kümede yer alan katılımcılar ise toplam katılımcıların \%20'sini oluşturmaktadır. 3. kümede feminen kimlik özelliklerine yüksek düzeyde sahip katılımcılar yer almaktadır. Bu kümenin katılımcıları maskulen kimlik özelliğini yansıtan güçlülük faktörü açısından ortalamanın altında, rekabet faktörü açısından ise düşük ortalamalara sahip kişilerdir. Bu nedenle 3. küme feminenler olarak adlandırılmıştır.

Her bir küme cinsiyet dağılımları açısından incelendiğinde hem feminen hem de maskulen kimlik özellikleri yüksek olan androjenler kümesinde yer alan katılımcıların büyük bir bölümünün (70\%) erkeklerden oluştuğu görülmektedir. Feminen kimlik özelliklerinin baskın olduğu feminenler kümesinde kadın ve erkek dağılımı açısından önemli bir fark görülmemekle birlikte, erkekler sayıca kadınların önünde yer almaktadır. Feminen ve maskulen kimlik özelliklerini belirgin biçimde taşımayan katılımcılardan oluşan belirsizler kümesi ise ağırlıklı olarak erkeklerden oluşmaktadır. Erkeklerin her üç kümede de nicelik açısından önde olmasının nedeni örneklemdeki erkek katılımcı ağırlığıdır $(\% 66,3)$.

Tablo 5: Katılımcıların Cinsiyet Kimliği Rolleri Açısından Profilleri

\begin{tabular}{|c|c|c|c|c|c|c|}
\hline \multirow{2}{*}{$\begin{array}{l}\text { Cinsiyet Kimliği } \\
\text { Rolleri }\end{array}$} & \multicolumn{2}{|c|}{$\begin{array}{l}\text { 1. Küme } \\
\text { ( } n=199)\end{array}$} & \multicolumn{2}{|c|}{$\begin{array}{c}\text { 2. Küme } \\
(n=54)\end{array}$} & \multicolumn{2}{|c|}{$\begin{array}{l}\text { 3. Küme } \\
(n=64)\end{array}$} \\
\hline & $\overline{\boldsymbol{X}}$ & $\mathbf{S}$ & $\overline{\boldsymbol{X}}$ & $\mathbf{S}$ & $\overline{\boldsymbol{X}}$ & $\mathbf{S}$ \\
\hline Sevecenlik & 4,07 & 0,55 & 2,84 & 0,57 & 4,25 & 0,45 \\
\hline Nezaket & 4,19 & 0,50 & 3,52 & 0,89 & 4,24 & 0,47 \\
\hline Güçlülük & 3,90 & 0,54 & 3,03 & 0,78 & 3,63 & 0,67 \\
\hline Rekabet & 3,78 & 0,65 & 2,62 & 0,76 & 1,95 & 0,53 \\
\hline
\end{tabular}


Tablo 6: Kümelerin Cinsiyet Dağılımları

\begin{tabular}{lcccccc}
\hline Kümeler & \multicolumn{2}{c}{ Kadın } & \multicolumn{2}{c}{ Erkek } & \multicolumn{2}{c}{ Toplam } \\
\hline & $\mathbf{n}$ & $\%$ & $\mathbf{n}$ & $\%$ & $\mathbf{n}$ & $\%$ \\
\hline Androjenler & 59 & 30 & 140 & 70 & 199 & 100 \\
Belirsizler & 19 & 35 & 35 & 65 & 54 & 100 \\
Feminenler & 28 & 44 & 36 & 56 & 64 & 100 \\
\hline
\end{tabular}

Her üç kümenin hediye satın alma davranışı açısından farklılaşıp farklılaşmadığını belirlemek için tek yönlü varyans analizi kullanılmıştır. Analiz sonucunda cinsiyet kimliği rolleri bakımından farklı özelliklere sahip üç kümenin hediye satın alma davranışları arasında istatistiksel olarak anlamlı bir fark bulunduğu görülmüştür. Küme ortalamaları incelendiğinde androjenler ve feminenlerin hediye satın alma davranışı bakımından ortalamanın üzerinde yüksek düzeyde bir performans gösterdikleri söylenebilir (Tablo 7). Belirsizler kümesinde yer alan katılımcıların hediye satın alma davranışı ise diğer iki kümenin gerisindedir. Feminen ve/veya maskulen kimlik özelliklerini belirgin biçimde taşıyan katılımcılar hediye satın almaya daha fazla önem verirken, cinsiyet kimlik özellikleri açısından belirsiz bir profile sahip katılımcıların hediye satın almaya verdikleri önem daha düşük düzeydedir.

Farklılığın hangi gruplardan kaynaklandığını belirlemek için yapılan Tukey karşılaştırma testi sonucunda androjenler ve belirsizler ile belirsizler ve feminenler arasında hediye satın alma davranışı açısından istatistiksel olarak anlamlı fark bulunmaktadır. Androjenler ve feminenlerin hediye satın alma davranışı açısından aralarında anlamlı bir farkın bulunmadığı tespit edilmiştir.

Tablo 7: Kümelerin Hediye Satın Alma Davranışı Ortalamaları

\begin{tabular}{lcc}
\hline Kümeler & $\overline{\boldsymbol{X}}$ & $\mathbf{S}$ \\
Androjenler & 3,47 & 0,75 \\
Belirsizler & 3,05 & 0,80 \\
Feminenler & 3,44 & 0,74 \\
\hline
\end{tabular}

Tablo 8: Kümelerin Hediye Satın Alma Davranışlarına İlişkin Varyans Analizi Sonuçları

\begin{tabular}{lcccccc}
\hline Varyansın Kaynağı & Kareler Toplamı & sd & $\begin{array}{c}\text { Kareler } \\
\text { Ortalaması }\end{array}$ & F & p & Anlamlı Fark \\
\hline Gruplar Arası & 7,677 & 2 & 3,838 & 6,569 & .002 & Androjenler-Belirsizler \\
\hline Gruplar İçi & 183,476 & 314 & 0,584 & & Belirsizler-Feminenler \\
\hline Toplam & 191,153 & 316 & & \\
\hline
\end{tabular}




\section{SONUÇ}

Tüketici davranışını etkileyen faktörleri konu alan çalışmalarda yaygın olarak kullanılan kriterlerden biri cinsiyettir. Bu çalışmalar kadınlarla erkeklerin birbirinden farklı ancak kendi içinde ortak özelliklerinin, bu iki grubun tüketim davranışlarını farklılaştırdığı savını ortaya koymakta ve bu sebeple cinsiyetin uygun bir pazar bölümlendirme kriteri olduğunu vurgulamaktadır. 1960'lardan itibaren tüketim araştırmalarında yer almaya başlayan bir başka bölümlendirme kriteri ise bireyin biyolojik değil, psikolojik kimliğini ifade eden cinsiyet kimliği rolü kavramıdır. Cinsiyet kimlikleri temelinde bireyler maskulen ve feminen bireyler olarak gruplandırılmaktadır. Feminen kimlik bireyin duygularının farkında olması ve bireylerarası etkileşime önem atfetmesi ile temsil edilirken, maskulen kimlik otorite ve güç kullanarak olayları, durumları ve insanları manipüle etmekle temsil edilmektedir. $\mathrm{Bu}$ nedenle her ne kadar feminen kimlik kadına has özelliklerle, maskulen kimlik ise erkeğe has özelliklerle ilişkilendirilse de bireyin psikolojik cinsiyeti olarak ifade edilen cinsiyet kimliği, biyolojik cinsiyetinden farklı olabilir. Bu durum "Pazar bölümlendirmede kadın ve erkek ayrımından mı, feminen ve maskulen ayrımından mı bahsetmek daha uygundur?" sorusunu akla getirmektedir. Bu bağlamda bu araştırmada bireylerin hediye satın alma davranışlarında cinsiyetlerinin ve cinsiyet kimliklerinin rolü ortaya konmaya çalışılmıştır.

Araştırma kapsamında katılımcıların hediye satın alma ve vermeye ilişkin tutum ve davranışları incelenmiştir. Araştırmanın en önemli bulgularından biri toplumda hediyeleşmeye ilişkin fillerin kullanımında yabancı yazınla bir uyuşmazlığın var olduğudur. Yabancı yazında hediye satın alma eyleminden ziyade hediyeyi sunma üzerinde durulmuş ve satın alma davranışı da "verme" fiili ile (gift giving) işlenmiştir. Hediye alma ise karşı taraftan hediye sunulmasını ifade etmektedir. Araştırma bulguları "hediye alma" fiilinin çoğunlukla satın alma eylemini ifade etmek için nadiren de başkasının kişiye hediye alması durumunda kullanıldığını göstermektedir. Benzer şekilde katılımcılar hediyeyi sunma eylemi üzerine çok fazla düşünmemekte, bunu bir ritüel olarak görmemekte, daha çok satın alma eylemi üzerine odaklanmaktadır. Bu sonuçla da bağlantılı olarak katılımcılar başkalarından hediye alma hatıralarından ziyade hediye satın alma ve verme anılarını hafızalarında tutmaktadırlar ve bu eğilim cinsiyetten de bağımsızdır.

Yabancı yazında hediye satın alma davranışının cinsiyete göre farklılaşmasını konu edinen çalışmalar literatür incelemesinde de belirtildiği gibi kadınların hediye satın almaya daha meyilli olduklarını ve daha çok birey odaklı satın almalar gerçekleştirdiğini ortaya koymaktadır. Araştırma bulguları ise katılımcıların hediye satın alma davranışlarında cinsiyete göre anlamlı bir farklılığın olduğunu göstermekle birlikte, hem kadınların hem de erkeklerin amaç odaklı satın almalar yaptıklarına işaret etmektedir. Bu farklılığın sebebinin de kültürel olduğu düşünülmektedir. Toplumumuzda hediyeleşme aynı zamanda bir yardımlaşma aracı olarak da görüldüğü için "alınan hediye işe yarasın" düşüncesiyle amaç odaklı satın almaların yapıldığı söylenebilir. Bir başka sebep de hediyeleşmenin daha çok özel günler münasebetiyle yapılıyor olmasıdır.

Araştırma kapsamında katılımcıların hediye satın alma davranışlarının cinsiyetlerinin yanı sıra cinsiyet kimliği rollerine göre de nasıl farklılaştığı incelenmiştir. Yabancı yazında bu konudaki çalışmalar literatür incelemesinde de sunulduğu gibi genel olarak dört farklı grubun varlığından bahsetmektedir. Hem feminen hem maskulen kimlik özellikleri güçlü olan bireyler androjenler, her iki kimlik özelliği de zayıf olan bireyler belirsizler olarak tanımlanmış ve feminen ve maskulen gruplar da ayrıca değerlendirilmiştir. Araştırma bulguları katılımcıların androjen, feminen ve belirsiz olmak üzere üç kümede toplandıklarını göstermektedir. Maskulen özellikleri baskın ya da feminen özellikleri zayıf bir kümeye ise rastlanmamıştır. Literatürde en çok hediye alma eğilimi taşıyan grup feminenler olarak tanımlanırken, araştırma bulguları androjenlerin en çok hediye almaya meyilli grup olduğunu, onları feminenlerin takip ettiğini göstermektedir. Belirsizlerin hediye alma eğilimleri ise her iki kümeden anlamlı ölçüde daha düşüktür. Elde edilen kümelerin cinsiyet dağılımları incelendiğinde erkek katılımcıların ağırlıklı olarak androjenler kümesinde toplandıkları görülmektedir. Erkek katılımcıların ağırlıkta olduğu ikinci küme ise feminenler kümesidir. Bu sonuç özelde hediye satın alma davranışında genelde ise tüketim araştırmalarında cinsiyetin yanı sıra cinsiyet kimliği rolünün de dikkate alınması gerektiğini ortaya koymaktadır. 
Satın alma davranışında yalnızca cinsiyeti bir pazar bölümlendirme değişkeni olarak dikkate aldığımızda androjenler kümesinde yer alan ve hediye satın almaya meyilli olan erkek katılımcıları gözden kaçırmamız muhtemeldir. Bu durum pazardaki potansiyelin değerlendirilememesi sonucunu doğuracaktır. Araştırma bulguları ışığında "Erkeklere ve kadınlara pazarlama stratejileri mi yoksa maskulenlere, feminenlere ve androjenlere pazarlama stratejileri mi?" sorusu tartışmaya açılmalıdır.

Tartışmaya açılması gereken bir başka nokta ise yerli literatürde cinsiyet kimliği rollerini ifade etmek için kullanılan kelimelerin nasıl Türkçeleştirileceği konusudur. Yabancı literatürde kullanılan maskulen, feminen ve androjen kelimeleri kelime anlamlarıla Türkçeleştirildiğinde kavramları tam olarak karşılamamakta ve cevaplayıcıların beyanlarını etkileyecek olumsuz algılara sebep olmaktadır. TDK'nın sözlüğüne göre feminen "kadınsı", maskulen "erkeksi" anlamına gelmekte iken "androjen" kelimesi ise sözlükte hiç yer almamaktadır. Kelimenin Ingilizce'den çevirisi ise "çift cinsiyetli" olarak yapılmakta ve psikolojik değil, biyolojik cinsiyeti ifade ettiğini düşündürmektedir. Tüketim araştırmalarında cinsiyet kimliği rolünün önemli etkisini ortaya koyabilmek ancak bu kavramların psikolojik cinsiyeti ifade edecek şekilde tercüme edilmesiyle mümkün olacaktır.

Araştırma zaman ve maliyet kısıtı nedeniyle üniversite personeli üzerinde kolayda örnekleme ile gerçekleştirilmiştir. Eğitim düzeyi yüksek ve tamamı çalışan bir kitle üzerinde yapılmış bir çalışma olmasının androjenler kümesindeki yoğunluğun en önemli sebebi olduğu düşünülmektedir. Bu nedenle feminen ve maskulen bireylerin de rahatlıkla gözlemlenebileceği örneklemlerde ve farklı satın alma kararları üzerine yapılan çalışmalarda araştırma sonuçlarını zenginleştirecek bulgulara ulaşılabileceği umulmaktadır.

\section{KAYNAKÇA}

Areni, C. S., Kiecker, P. Ve Palan, K. M. (1998) “Is It Better to Give than to Receive? Exploring Gender Differences in the Meaning of Memorable Gifts" Psychology \& Marketing, 15(1): 81-109.

Çabuk, S. ve Köksal Araç, S. (2013) "Psikografik Bir Bölümlendirme Değişkeni Olarak Cinsiyet Kimliği: Tüketim Araştırmalarında Cinsiyet Kimliği Kavramının İncelenmesi" Çukurova Üniversitesi Sosyal Bilimler Enstitüsü Dergisi, 22(2): 27-40.

Dalakas, V. ve Shoham, A. (2010) "Gender-Role Views and Gift-Giving Behaviors in Israel" Journal of Consumer Marketing, 27(4): 381-389.

Demez, G. (2011) "Armağanın Değişen SosyoKültürel Anlamları: Tüketim Toplumu Bağlamında Bir Hediyeleşme Örneği Olarak Çiçek Gönderme" Mediterranean Journal of Humanities, 1(2): 87-103.

Fischer, E. ve Arnold, S. C. (1990) “More Than A Labor of Love: Gender Role and Christmas Gift Shopping" Journal of Consumer Research, 17: 333-345.

Hair, J. F., Anderson, R. E., Tatham, R. L. ve Black, W.C. (1998) Multivariate Data Analysis 5th Edition, New Jersey, Prentice-Hall.

Huang, M. ve Yu, S. (2000) "Gifts in Romantic Relationship: A Survival Analysis" Journal of Consumer Psychology, 9(3): 179-188.
Klein, J. G., Lowrey, T. M. ve Otnes, C. C. (2015) "Identity-Based Motivations and Anticipated Reckoning: Contributions to Gift-Giving Theory from an Identity-Stripping Context" Journal of Consumer Psychology. Avaliable online on January 2015 (http://www.sciencedirect.com/science/article/pii/ S1057740815000078)

Larsen, D. ve Watson, J. J. (2001) "A Guide Map to The Terrain of Gift Value" Psychology \& Marketing, 18(8): 889-906.

Malhotra, N. K. (2007) Marketing Research: An Applied Orientation, 5th Edition, New Jersey, Prentice-Hall.

McGrath, M. A. (1995) "Gender Differences in Gift Exchange: New Directions From Projections" Psychology \& Marketing, 12(5): 371-393.

Minami, C. (1994) "Gift-Giving Behavior: A Ritual or an Economic Exchange?" Advances in Consumer Studies (Japan), 2(1): I-28.

Minowa, Y., Khomenko, O. ve Belk, R. W. (2011) "Social Change and Gendered Gift-Giving Rituals: A Historical Analysis of Valentine's Day in Japan" Journal of Macromarketing, 31(1): 44-56.

Otnes, C., Ruth, J. A. ve Milbourne, C. C. (1994) "The Pleasure and Pain of Being Close: Men's Mixed Feelings About Participation in Valentine's Day Gift Exchange" Advances in Consumer Research, 21: 159164. 
Palan, K., Areni, C. S. ve Kiecker, P. (2001) "Gender Role Incongruency and Memorable Gift Exchange Experiences" Advances in Consumer Research, 28: 5157.

Pollmann, M. M. H. ve Beest, I. V. (2013) “Women Are Better at Selecting Gifts than Men" PLOS One, 8(12): 1-6.

Schertzer, S. M.B., Laufer, D., Silvera, D. H. ve McBride, B. J. (2008) "A Cross-Cultural Validation of a Gender Role Identity Scale in Marketing" International Marketing Review, 25(3): 312-323.

Schiffman, L. G. ve Cohn, D. Y. (2009) “Are They Playing by The Same Rules? A Consumer Gifting Classification of Marital Dyads" Journal of Business Research, 62: 1054-1062.
Shanka, T. ve Handley, B. (2011) "Gift Giving: An Exploratory Behavioural Study" Asia Pacific Journal of Tourism Research, 16(4): 359-377.

Sherry, J. F. (1983) "Gift Giving in Anthropological Perspective" The Journal of Consumer Research, 10(2): 157-168.

Ward, C. B. ve Tran, T. (2007) "Consumer Gifting Behaviors: One For You, One For Me" Services Marketing Quarterly, 29(2): 1-17.

Webster, C. ve Nottingham, L. (2000) "Gender Differences in The Motivations for Gift Giving" AMA Conference Proceedings, 11:272-278.

Wolfinbarger, M. F. ve Gilly, M. C. (1996) "An Experimental Investigation of Self-Symbolism in Gifts" Advances in Consumer Research, 23: 458-462. 